\title{
Engineering geological characteristics of the underground surge pool cavern: a case study, India
}

\author{
A. K. Naithani* ${ }^{\mathbb{B}}$, Prasnna Jain, L. G. Singh and D. S. Rawat
}

*Correspondence:

anaithania@gmail.com

National Institute of Rock

Mechanics, Bengaluru, India

\begin{abstract}
For better rock mass characterization, 3D engineering geological mapping and in-situ testing was carried for the heading portion of surge pool of Palamuru Ranga Reddy lift irrigation scheme lift-II. The direction of the longest axis of the surge pool cavern was finalized based on the in-situ hydrofracturing testing inside the borehole and aligning the appurtenant structures of pump house and surge pool cavern on the ground. Rock types mapped were grey and pink granites belongs to the Peninsular Gneissic Complex of Archaean age. The assessment of Tunnel Quality Index ' $Q$ ' for the exposed granitic rock mass was done based on the information available of the rock joints and their nature, 3D geological mapping and in-situ stress measurement. The rock mass quality (Q) is related with the ultimate support pressure requirement. Excavation Support Ratio (ESR) as given in the ESR updated classification standard of NMT Q-system is applied to 1.0 for this cavern. On the basis of NMT Q-system chart and site geological characteristics, support system is recommended and its efficacy is assessed.
\end{abstract}

Keywords: Engineering geology, Surge pool cavern, Support system, Rock bolt, Steel fibre reinforced shotcrete

\section{Introduction}

$357.00 \mathrm{~m}$ long, $89.81 \mathrm{~m}$ high and $31.00 \mathrm{~m}$ wide underground surge pool cavern for a lift irrigation scheme is being constructed in the part of Telangana State of India. The main design approaches for underground cavern excavation in rock are analytical, observational, and empirical. In this paper empirical approach for support design of underground surge pool cavern of a Palamuru Ranga Reddy lift irrigation scheme liftII (PRLIS-L-II) is discussed. Rock mass classifications as practiced in civil and mining engineering works form an integral part of the empirical design methods, which is the most predominant design approach [4]. The main objectives of the rock mass classifications are to identify the most significant parameters influencing the behavior of a rock mass, divide area into rock mass classes of varying quality and provide quantitative data for engineering design purpose. Empirical approaches are developed for the stability of underground structures based on the large number of case studies.

(c) The Author(s) 2022. Open Access This article is licensed under a Creative Commons Attribution 4.0 International License, which permits use, sharing, adaptation, distribution and reproduction in any medium or format, as long as you give appropriate credit to the original author(s) and the source, provide a link to the Creative Commons licence, and indicate if changes were made. The images or other third party material in this article are included in the article's Creative Commons licence, unless indicated otherwise in a credit line to the material. If material is not included in the article's Creative Commons licence and your intended use is not permitted by statutory regulation or exceeds the permitted use, you will need to obtain permission directly from the copyright holder. To view a copy of this licence, visit http:// creativecommons.org/licenses/by/4.0/. 
Table 1 Summary of input data

\begin{tabular}{|c|c|c|c|c|c|}
\hline 1. & Length of surge pool & $357.00 \mathrm{~m}$ & 9. & Rise of arc & $9.00 \mathrm{~m}$ \\
\hline 2. & Excavated width of cavern (B) & $31.00 \mathrm{~m}$ & 10. & Bottom floor level & $274.19 m$ \\
\hline 3. & Height of surge pool & $89.81 \mathrm{~m}$ & 11. & Minimum down surge level & $313.89 \mathrm{~m}$ \\
\hline 4. & Height of surge pool walls & $80.81 \mathrm{~m}$ & 12. & Maximum upsurge level & $341.80 \mathrm{~m}$ \\
\hline 5. & Crown level & $364.00 \mathrm{~m}$ & 13. & Service bay level & $346.0 \mathrm{~m}$ \\
\hline 6. & Spring level & $355.00 \mathrm{~m}$ & 14. & Vertical stress $\left(\sigma_{v}\right)$ & $3.44 \mathrm{MPa}$ \\
\hline 7. & $\begin{array}{l}\text { Height of overburden above } \\
\text { crown }(\mathrm{H})\end{array}$ & $67.48 \mathrm{~m}$ (average) & 15. & $\begin{array}{l}\text { Maximum horizontal principal } \\
\text { stress }\left(\sigma_{H}\right)\end{array}$ & $5.46 \pm 1.23 \mathrm{MPa}$ \\
\hline 8. & Ground levels & $431.48 \mathrm{~m}$ & 16. & $\begin{array}{l}\text { Minimum horizontal principal } \\
\text { stress }\left(\sigma_{h}\right)\end{array}$ & $3.64 \pm 0.82 \mathrm{MPa}$ \\
\hline
\end{tabular}

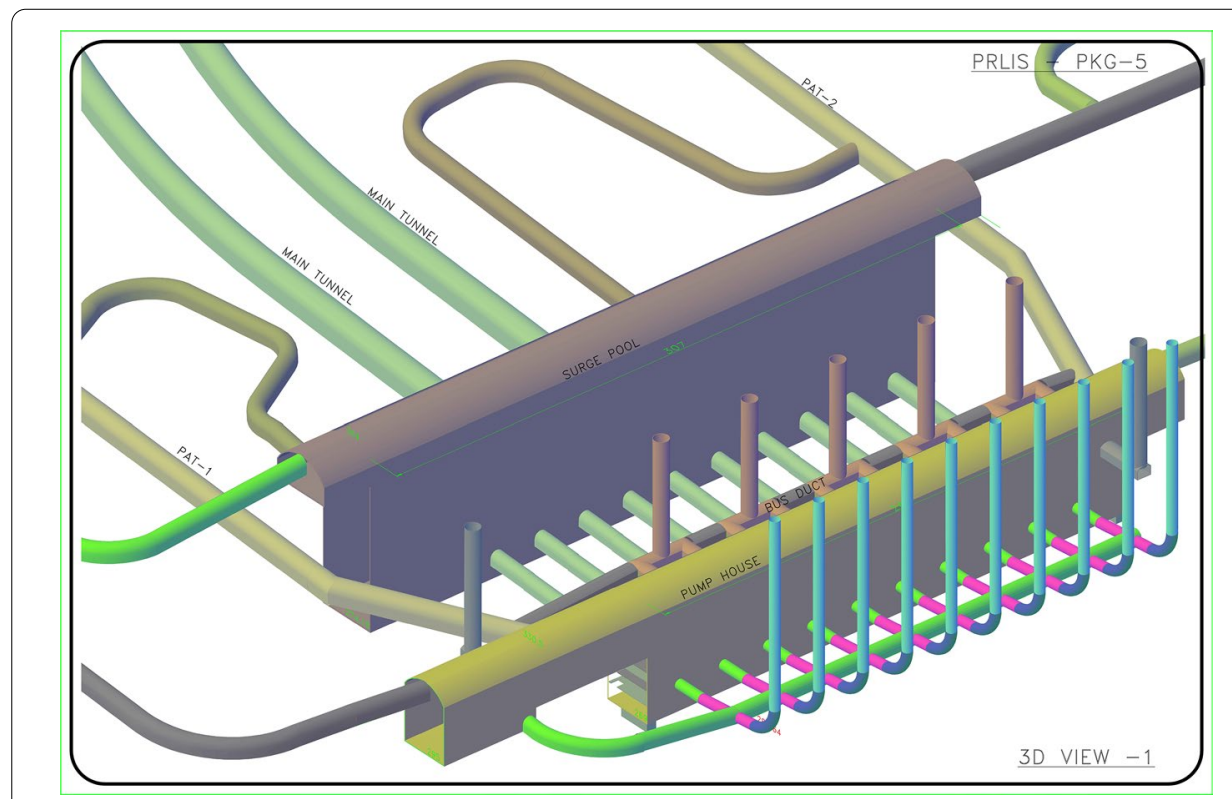

Fig. $13 D$ view of pump house complex including surge pool and pump house

For surge pool cavern of PRLIS lift-II, rock mass characterization was done based on 3D geologic mapping and in-situ stress measurement. For the orientation of the long axis of the surge pool underground cavern, hydrofrac test inside the NX borehole BH-01 was carried out by NIRM. Vertical borehole (BH-01) of $130 \mathrm{~m}$ depth was drilled from the surface. From this test, magnitudes of the principal stresses as well as the direction of maximum horizontal principal stress were determined. After detailed analysis it was concluded that the K-value $\left(\sigma_{\mathrm{H}} / \sigma_{\mathrm{v}}=1.58\right)$ indicates a medium stress magnitude and the maximum horizontal principal stress direction $\mathrm{N} 30^{\circ}$, which was recommended for the orientation of the long axis of the cavity to reduce ground control problems [1]. For this cavern the vertical cover is more than $67 \mathrm{~m}$ and summary of input data used for the recommendation of support system for underground surge pool cavern is given in Table 1 and 3D view of pump house complex including surge pool and pump house is given in Fig. 1. 


\section{Site geological condition}

Surge pool site of Palamuru Ranga Reddy lift irrigation scheme lift-II forms a part of the Peninsular Shield of the Indian Sub-continent [16]. The site forms a part of Eastern Block of Dharwar Craton mainly comprised of Archaean granites which are intruded by mafic dykes age ranging from Archaean to Upper Proterozoic [18]. Granites and gneisses are exposed in and around the surge pool area. Granites and gneisses have deformational history documenting three phases of folding $[7,16]$. Granites and gneisses are intruded by different types of younger granites [17]. The surge pool area exhibits a gently undulated topography with isolated hillocks and undulated hilly terrain with intermittent broad valley portions. On the surface along the surge pool alignment medium to coarse grained pink/grey granites were exposed.

$3 \mathrm{D}$ engineering geological mapping of the heading portion of surge pool cavern was carried out in 1:100 scale. This will be a permanent record of all geologic defects present in the excavated portion. After proper cleaning and scaling, in adequate lighting geological logging was done. Rock types mapped after the excavation were grey and pink granite belongs to the Peninsular Gneissic Complex of Archaean age [15, 16]. Granites were medium to coarse grained, hard, jointed and fresh in nature.

The rock mass was characterized by generally two plus random joint sets, which were generally more than $15 \mathrm{~m}$ in persistent, slightly rough, rough undulating, rough planar to smooth planar, with unaltered joint walls (Table 2). Minor staining has been recorded along some joint surfaces. Joints were moderately to widely spaced in nature. The rock mass was characterized by dry condition. Minor cracks/fractures developed due to blasting were also recorded.

About $20 \mathrm{~cm}$ wide dolerite dyke was recorded towards right side edge, where the granite rock mass was sheared at the contact with the dyke. Dolerite dyke was fresh, hard and compact in nature. However, the contact zones of dolerite and the adjoining granite were slightly sheared. Along the contact zones i.e., over a width of $0.40 \mathrm{~m}$, welded wire mesh was placed and $50 \mathrm{~mm}$ extra SFRS layer was put to prevent any rock fall during benching down.

Table 2 Joint sets recorded in pink/grey granite

\begin{tabular}{|c|c|c|c|c|c|c|c|}
\hline Joint sets & $\begin{array}{l}\text { Azimuth/ } \\
\text { dip amount }\end{array}$ & $\begin{array}{l}\text { Spacing } \\
(\mathrm{cm})\end{array}$ & $\begin{array}{l}\text { Strike } \\
\text { length }(m)\end{array}$ & Roughness & $\begin{array}{l}\text { Aperture } \\
(\mathrm{mm})\end{array}$ & Infilling & $\begin{array}{l}\text { Ground } \\
\text { water }\end{array}$ \\
\hline J1 & $280-310 / N$ & $20-60$ & $>20$ & $\begin{array}{l}\text { Slightly } \\
\text { rough, } \\
\text { smooth } \\
\text { planar }\end{array}$ & Tight to 1 & $\begin{array}{l}\text { Fresh/ } \\
\text { stained }\end{array}$ & Dry \\
\hline$J 2$ & 220/10-15 & $30-40$ & $10-20$ & $\begin{array}{l}\text { Slightly } \\
\text { rough, } \\
\text { smooth } \\
\text { planar }\end{array}$ & Tight to 1 & $\begin{array}{l}\text { Fresh/ } \\
\text { stained }\end{array}$ & Dry \\
\hline$J 3$ & $220 / \mathrm{N}$ & $20-70$ & $>20$ & $\begin{array}{l}\text { Rough undu- } \\
\text { lating }\end{array}$ & Tight to 1 & $\begin{array}{l}\text { Fresh/ } \\
\text { stained }\end{array}$ & Dry \\
\hline$J 4$ & 130/60-65 & $30-40$ & $>15$ & $\begin{array}{l}\text { Smooth } \\
\text { planar }\end{array}$ & Tight to 1 & $\begin{array}{l}\text { Fresh/ } \\
\text { stained }\end{array}$ & Dry \\
\hline$J 5$ & $30-50 / \mathrm{N}$ & $20-70$ & $>20$ & $\begin{array}{l}\text { Rough } \\
\text { planar }\end{array}$ & Tight & Fresh & Dry \\
\hline
\end{tabular}




\section{Rock mass classification}

The rock mass of the heading portion of surge pool cavern was classified based on tunnelling quality index $(Q)$. Based on six parameters i.e. rock quality designation $(R Q D)$, number of joint sets $\left(J_{n}\right)$, joint roughness number $\left(J_{r}\right)$, joint alteration number $\left(J_{a}\right)$, joint water reduction factor $\left(J_{w}\right)$ and stress reduction factor $(S R F)$, the Q-values are calculated using the Eq. (1) [2, 5, 6]. High Q-values means good stability while low Q-values indicates poor stability. World-wide this classification is being used for the characterization of rock mass of an underground opening in jointed rock masses.

$$
Q=\frac{R Q D}{J_{n}}+\frac{J_{r}}{J_{a}}+\frac{J_{w}}{S R F}
$$

All the parameters were determined during geological mapping using tables that give numerical values to be assigned to a described situation. All the discontinuities per $5 \mathrm{~m}$ length were taken into consideration for the calculation of Q-values and in general two plus random $(\mathrm{R})$ joint sets were intersecting at $5 \mathrm{~m}$ length and circumference. RQD values were ranging from 60 to $80 \%$ and average RQD value was $70 \%$. Total excavation was done in dry condition. The assessment of Q-values based on the information available of the rock joints and their nature and 3D geological logging, is tabulated in Table 3. Roof support pressure, wall support pressure and ground squeezing condition were estimated based on Q-values. The grade of rock mass based on the rock joints characteristics has the Q-values varying from 3.89 to 13.33 , and it comes under poor to good rock mass category. The average Q-value calculated is 10.87 . The poor Q-value was estimated at the intersection portion only.

\section{Estimation of support pressure and ground squeezing condition}

Barton et al. [2] gives an empirical equation relating rock mass quality 'Q' and permanent support pressure based on the case records Eq. (2). They also give an improved empirical fit by incorporating separate weighting for the number of joint sets $\left(J_{n}\right)$ Eq. (3). For the surge pool cavern of PRLIS lift-II, roof support and wall support pressures are estimated as per Eqs. (4) and (5), which are applicable for the non-squeezing ground condition $[8,19]$.

$$
\begin{aligned}
& P_{\text {roof }}=\frac{2.0}{J_{r}} Q^{-1 / 3} \\
& P_{\text {roof }}=\frac{2 J_{n}^{1 / 2}(Q)^{-1 / 3}}{3 J_{r}} \\
& P_{\text {roof }}=\frac{2.0}{J_{r}} Q^{-1 / 3} \times f \\
& P_{\text {Wall }}=\frac{2.0}{J_{r}} Q_{w}^{-1 / 3} \times f
\end{aligned}
$$


Table 3 Q-values recorded from the heading portion of the surge pool

\begin{tabular}{|c|c|c|c|c|c|c|c|c|c|}
\hline \multirow{2}{*}{$\begin{array}{l}\text { Chainage } \\
\text { (m) }\end{array}$} & \multirow[t]{2}{*}{ Rock type } & \multirow{2}{*}{$\begin{array}{l}\text { Rock quality } \\
\text { designation } \\
\text { (\%) }\end{array}$} & \multirow{2}{*}{$\begin{array}{l}\text { Number } \\
\text { of joint } \\
\text { sets }\end{array}$} & \multirow{2}{*}{$\begin{array}{l}\text { Joint } \\
\text { roughness } \\
\text { number }\end{array}$} & \multirow{2}{*}{$\begin{array}{l}\text { Joint } \\
\text { alteration } \\
\text { number }\end{array}$} & \multirow{2}{*}{$\begin{array}{l}\text { Joint water } \\
\text { reduction } \\
\text { factor }\end{array}$} & \multirow{2}{*}{$\begin{array}{l}\text { Stress } \\
\text { reduction } \\
\text { factor }\end{array}$} & \multicolumn{2}{|l|}{$\mathrm{Q}$} \\
\hline & & & & & & & & Value & Class \\
\hline $0-10$ & $\begin{array}{l}\text { Medium } \\
\text { to coarse } \\
\text { granite }\end{array}$ & 70 & $\begin{array}{l}2+R \\
\text { (intersec- } \\
\text { tion) }\end{array}$ & $\begin{array}{l}\text { Smooth, } \\
\text { planar }\end{array}$ & Unaltered & $\begin{array}{l}\text { Dry excava- } \\
\text { tion }\end{array}$ & $\begin{array}{l}\text { Medium } \\
\text { stress }\end{array}$ & 3.89 & Poor \\
\hline $10-25$ & $\begin{array}{l}\text { Medium } \\
\text { to coarse } \\
\text { granite }\end{array}$ & 70 & $2+R$ & $\begin{array}{l}\text { Smooth, } \\
\text { planar }\end{array}$ & $\begin{array}{l}\text { Unaltered, } \\
\text { stained }\end{array}$ & $\begin{array}{l}\text { Dry excava- } \\
\text { tion }\end{array}$ & $\begin{array}{l}\text { Medium } \\
\text { stress }\end{array}$ & 11.67 & Good \\
\hline $25-50$ & $\begin{array}{l}\text { Medium } \\
\text { to coarse } \\
\text { granite }\end{array}$ & 65 & $2+R$ & $\begin{array}{l}\text { Smooth, } \\
\text { planar }\end{array}$ & Unaltered & $\begin{array}{l}\text { Dry excava- } \\
\text { tion }\end{array}$ & $\begin{array}{l}\text { Medium } \\
\text { stress }\end{array}$ & 10.83 & Good \\
\hline $50-75$ & $\begin{array}{l}\text { Medium } \\
\text { to coarse } \\
\text { granite }\end{array}$ & 80 & $2+R$ & $\begin{array}{l}\text { Smooth, } \\
\text { planar }\end{array}$ & Unaltered & $\begin{array}{l}\text { Dry excava- } \\
\text { tion }\end{array}$ & $\begin{array}{l}\text { Medium } \\
\text { stress }\end{array}$ & 13.33 & Good \\
\hline $75-100$ & $\begin{array}{l}\text { Medium } \\
\text { to coarse } \\
\text { granite }\end{array}$ & 75 & $2+R$ & $\begin{array}{l}\text { Smooth, } \\
\text { planar }\end{array}$ & $\begin{array}{l}\text { Unaltered, } \\
\text { stained }\end{array}$ & $\begin{array}{l}\text { Dry excava- } \\
\text { tion }\end{array}$ & $\begin{array}{l}\text { Medium } \\
\text { stress }\end{array}$ & 12.50 & Good \\
\hline $100-125$ & $\begin{array}{l}\text { Medium } \\
\text { to coarse } \\
\text { granite }\end{array}$ & 70 & $2+R$ & $\begin{array}{l}\text { Smooth, } \\
\text { planar }\end{array}$ & $\begin{array}{l}\text { Unaltered, } \\
\text { stained }\end{array}$ & $\begin{array}{l}\text { Dry excava- } \\
\text { tion }\end{array}$ & $\begin{array}{l}\text { Medium } \\
\text { stress }\end{array}$ & 11.66 & Good \\
\hline $125-150$ & $\begin{array}{l}\text { Medium } \\
\text { to coarse } \\
\text { granite }\end{array}$ & 75 & 3 & $\begin{array}{l}\text { Smooth, } \\
\text { planar }\end{array}$ & Unaltered & $\begin{array}{l}\text { Dry excava- } \\
\text { tion }\end{array}$ & $\begin{array}{l}\text { Medium } \\
\text { stress }\end{array}$ & 8.33 & Fair \\
\hline 150-175 & $\begin{array}{l}\text { Medium } \\
\text { to coarse } \\
\text { granite }\end{array}$ & 80 & $2+R$ & $\begin{array}{l}\text { Smooth, } \\
\text { planar }\end{array}$ & $\begin{array}{l}\text { Unaltered, } \\
\text { stained }\end{array}$ & $\begin{array}{l}\text { Dry excava- } \\
\text { tion }\end{array}$ & $\begin{array}{l}\text { Medium } \\
\text { stress }\end{array}$ & 13.33 & Good \\
\hline $175-200$ & $\begin{array}{l}\text { Medium } \\
\text { to coarse } \\
\text { granite }\end{array}$ & 60 & $2+R$ & $\begin{array}{l}\text { Smooth, } \\
\text { planar }\end{array}$ & Unaltered & $\begin{array}{l}\text { Dry excava- } \\
\text { tion }\end{array}$ & $\begin{array}{l}\text { Medium } \\
\text { stress }\end{array}$ & 10.00 & Good \\
\hline 200-239 & $\begin{array}{l}\text { Medium } \\
\text { to coarse } \\
\text { granite }\end{array}$ & 70 & $2+R$ & $\begin{array}{l}\text { Smooth, } \\
\text { planar }\end{array}$ & $\begin{array}{l}\text { Unaltered, } \\
\text { stained }\end{array}$ & $\begin{array}{l}\text { Dry excava- } \\
\text { tion }\end{array}$ & $\begin{array}{l}\text { Medium } \\
\text { stress }\end{array}$ & 11.67 & Good \\
\hline $239-260$ & $\begin{array}{l}\text { Medium } \\
\text { to coarse } \\
\text { granite }\end{array}$ & 65 & $2+R$ & $\begin{array}{l}\text { Smooth, } \\
\text { planar }\end{array}$ & $\begin{array}{l}\text { Unaltered, } \\
\text { stained }\end{array}$ & $\begin{array}{l}\text { Dry excava- } \\
\text { tion }\end{array}$ & $\begin{array}{l}\text { Medium } \\
\text { stress }\end{array}$ & 10.83 & Good \\
\hline $260-285$ & $\begin{array}{l}\text { Medium } \\
\text { to coarse } \\
\text { granite }\end{array}$ & 60 & $2+R$ & $\begin{array}{l}\text { Smooth, } \\
\text { planar }\end{array}$ & Unaltered & $\begin{array}{l}\text { Dry excava- } \\
\text { tion }\end{array}$ & $\begin{array}{l}\text { Medium } \\
\text { stress }\end{array}$ & 10.00 & Good \\
\hline $285-300$ & $\begin{array}{l}\text { Medium } \\
\text { to coarse } \\
\text { granite }\end{array}$ & 70 & $2+R$ & $\begin{array}{l}\text { Smooth, } \\
\text { planar }\end{array}$ & $\begin{array}{l}\text { Unaltered, } \\
\text { stained }\end{array}$ & $\begin{array}{l}\text { Dry excava- } \\
\text { tion }\end{array}$ & $\begin{array}{l}\text { Medium } \\
\text { stress }\end{array}$ & 11.67 & Good \\
\hline $300-357$ & $\begin{array}{l}\text { Medium } \\
\text { to coarse } \\
\text { granite }\end{array}$ & 75 & $2+R$ & $\begin{array}{l}\text { Smooth, } \\
\text { planar }\end{array}$ & Unaltered & $\begin{array}{l}\text { Dry excava- } \\
\text { tion }\end{array}$ & $\begin{array}{l}\text { Medium } \\
\text { stress }\end{array}$ & 12.50 & Good \\
\hline
\end{tabular}

where $P_{\text {roof }}$ is permanent/ultimate roof support pressure in $\mathrm{kg} / \mathrm{cm}^{2}, P_{\text {wall }}$ is ultimate wall support pressure in $\mathrm{kg} / \mathrm{cm}^{2}, J r$ is joint roughness number, $Q$ is rock mass quality, $Q_{w}$ is wall quality/factor equal to $2.5 Q$ for intermediate qualities $(0.1<Q<10)$ and $5 Q$ for good qualities $(Q>10)$ in case of medium stress, $J_{n}$ is joint set number and $f$ is correction factor for overburden. Correction factor for overburden can be estimated from Eq. (6), where ' $H$ ' is the height of overburden above crown in metres.

$$
f=1+\frac{(H-320)}{800} \geq 1=1+\frac{(67.48-320)}{800}=0.68
$$

For the estimation of non-squeezing ground condition Singh et al. [19] suggested an empirical approach Eq. (7) based on case histories and by collecting Barton et al. [2] 
' $Q$ ' data and overburden $(H)$. Minimum Q-value is used for the estimation of ground squeezing condition. Ground condition is non-squeezing because above surge pool cavern, cover is $67.48 \mathrm{~m}$ only. The required support pressure for crown is varying between 8.437 and $9.869 \mathrm{t} / \mathrm{m}^{2}$ and for walls $4.934-7.271 \mathrm{t} / \mathrm{m}^{2}$ (Table 4). The average support pressure for crown is $8.927 \mathrm{t} / \mathrm{m}^{2}$ and for walls $5.336 \mathrm{t} / \mathrm{m}^{2}$.

$$
H<350 Q^{1 / 3} ; 67.48<350 \times 8.33^{1 / 3}=709
$$

\section{Rock support}

As per hydraulic design, the surge pool of lift-II scheme is having an excavated width of $31.00 \mathrm{~m}$ and length $357.00 \mathrm{~m}$. The crown level of surge pool is kept at EL $364.00 \mathrm{~m}$ and bottom level at EL $274.19 \mathrm{~m}$. As per hydraulic design, the maximum upsurge level of surge pool works out to EL $341.80 \mathrm{~m}$ and minimum down surge level works out to EL $313.89 \mathrm{~m}$. Surge pool with $500 \mathrm{~mm}$ thick concrete lined in the lower portion is proposed. For the heading portion of surge pool cavern reinforcement support pattern using Norwegian Method of Tunnelling (NMT) Q-system was used. Excavation Support Ratio (ESR) of cavity as given in the ESR updated classification standard of NMT Q-system is applied to 1.0 [14]. The Equivalent Dimension (De) is applied by dividing the span (m) of surge pool cavern by the fore-mentioned ESR. Bolt length which is depend on excavation dimension can be estimated from the excavation span (B) and the excavation support ratio (ESR) [2, 3] Eq. (8). By applying this formula, the length of rock bolt for the crown is calculated to be $6.65 \mathrm{~m}$. The value of NMT Q-system chart proposed is $7.0-8.0 \mathrm{~m}$ for the crown:

$$
L_{\text {roof }}=2+\frac{0.15 B}{E S R}
$$

where $L_{\text {roof }}$ is bolt length in metres for roof, $B$ is span in metres and $E S R$ is the excavation support ratio.

The Norwegian Institute for Rock Blasting Technique has proposed a formula Eq. (9) to estimate the length of the bolts in the central section of the opening where ' $B$ ' is the span of the opening in metres [22]. By applying this, the length of rock bolt for crown of surge pool is calculated to be $7.10 \mathrm{~m}$ Eq. (9).

$$
\mathrm{L}=1.40+0.184 \mathrm{~B}
$$

The thickness of steel fibre reinforced shotcrete $\left(t_{f s}\right)$ can be estimated from the ultimate support pressure $\left(P_{\text {roof }}\right)$, size of opening $(B)$, mobilization factor for shotcrete $\left(F_{f s c}-0.6 \pm 0.05\right)$ and shear strength of steel fibre reinforced shotcrete $\left(q_{f s c}-550 \mathrm{t} /\right.$ $\mathrm{m}^{2}$ ) as per Eq. (10) [9]. The thickness of SFRS for crown is calculated from the average Q-value to be $150 \mathrm{~mm}$. The value of NMT Q-system chart proposed is 70-90 $\mathrm{mm}$ for crown.

$$
t_{f s c}=\frac{P_{\text {roof }} \times B \times F_{f s c}}{2 q_{f s c}}
$$




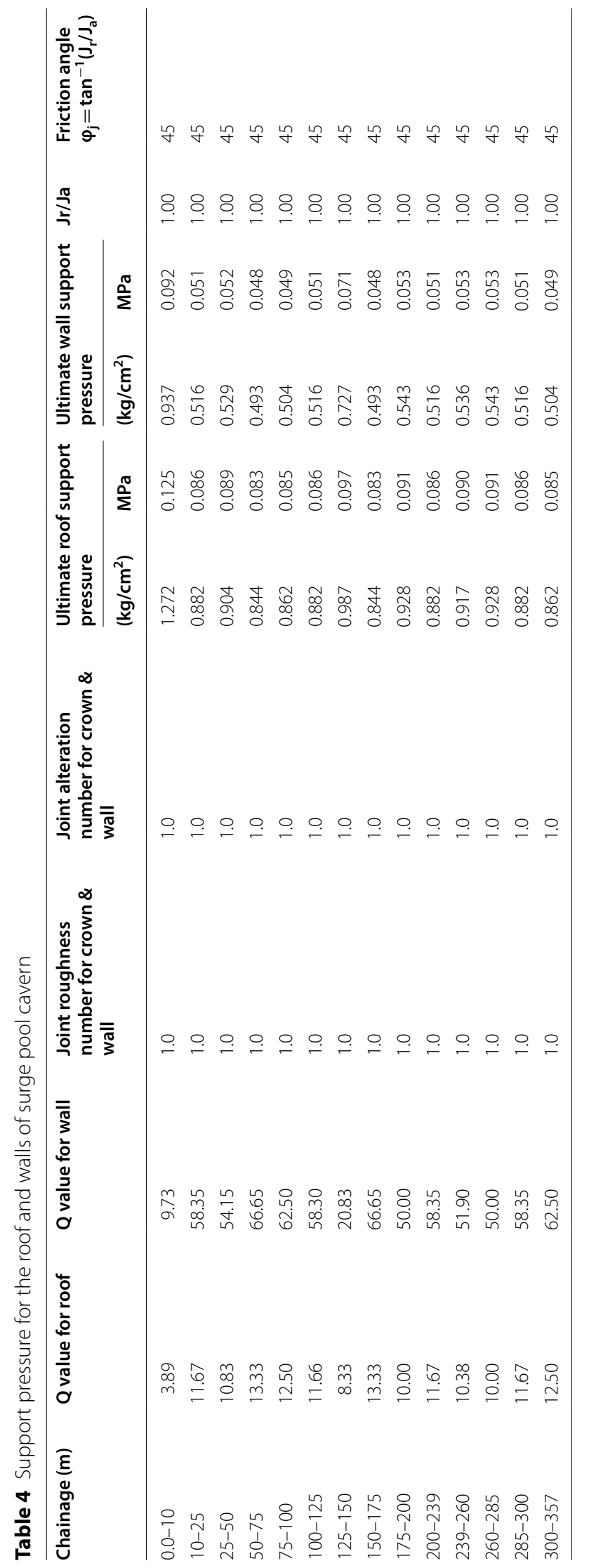


For structural stability of heading portion of surge pool, rock support arrangements include $6 \mathrm{~m}$ long, $25 \mathrm{~mm}$ diameter fully cement grouted (Fe500) at $1500 \mathrm{~mm} \mathrm{c} / \mathrm{c}$ staggered rock bolts and $150 \mathrm{~mm}$ thick steel fibre reinforced shotcrete (SFRS) in three layers were performed. Consolidation grouting using $45 \mathrm{~mm}$ dia. holes at $6 \mathrm{~m} \mathrm{c} / \mathrm{c}$ spacing and up to $6 \mathrm{~m}$ depth was also done. $7.0 \mathrm{~m}$ long and $50 \mathrm{~mm}$ diameter drain holes at $6.0 \mathrm{~m} \mathrm{c} / \mathrm{c}$ were also placed for controlling the underground seepage water if any in future (Fig. 2).

\section{Estimation of support system capacity}

Integrated approach given by Singh et al. [20], Singh and Goel [21] and IS: 15026 [9] is used for the determination of surge pool crown support system capacity. Earlier this approach was used for the construction of underground caverns in the similar type of terrain [10-13]. The total support pressure $\left(u+p_{\text {roof }}\right)$ will be equal to the sum of capacities of support system executed at the crown portion Eq. (11):

$$
u+p_{\text {roof }}=p_{s c}+p_{\text {bolt }}+p_{g t}
$$

where $u=$ seepage water pressure $=0.0 \mathrm{t} / \mathrm{m}^{2}, p_{\text {roof }}=$ roof support pressure (varying from 8.437 to $\left.9.869 \mathrm{t} / \mathrm{m}^{2}\right), p_{s c}=$ capacity of SFRS $\left(\mathrm{t} / \mathrm{m}^{2}\right), p_{\text {bolt }}=$ capacity of rock bolts $\left(\mathrm{t} / \mathrm{m}^{2}\right)$, $p_{g t}=$ capacity of grouted rock $\operatorname{arch}\left(\mathrm{t} / \mathrm{m}^{2}\right)$.

It is assumed that the SFRS is intimately in contact with the rock mass and having the tendency to fail by shearing and the capacity of SFRS is estimated as per Eq. (12). For the roof the capacity of SFRS estimated is $8.188 \mathrm{t} / \mathrm{m}^{2}$.

$$
p_{f s c}=\frac{2 q_{f s c} \times t_{f s c}}{B F_{f s c}}
$$

where $p_{s c}=$ support capacity of SFRS lining $\left(\mathrm{t} / \mathrm{m}^{2}\right), q_{f s c}=$ shear strength of SFRS (550 t/ $\left.\mathrm{m}^{2}\right), t_{f s c}=$ thickness of SFRS, $B=$ size of opening, $F_{f s c}=$ mobilization factor for shotcrete $(0.6 \pm 0.05$ - higher for cavern $)$.

The capacity of $6 \mathrm{~m}$ long, $25 \mathrm{~mm}$ diameter rock bolt is estimated as per Eq. (13) and the minimum capacity for surge pool roof calculated is $2.952 \mathrm{t} / \mathrm{m}^{2}$.

$$
p_{\text {bolt }}=\frac{2 q_{c r m} \times l^{\prime} \sin \theta}{B F_{s}}
$$

where $p_{\text {bolt }}=$ capacity of rock bolt $\left(\mathrm{t} / \mathrm{m}^{2}\right), q_{c r m}=\mathrm{UCS}$ of reinforced rock mass, $l^{\prime}=$ thickness of reinforced rock arch/rock column, $\theta=60 ; \sin \theta=0.865, B=$ size of opening in $\mathrm{m}$, $F_{s}=$ mobilization factor for rock bolts.

UCS of reinforced rock mass for the surge pool crown is calculated as per Eqs. (14) and (15) was $49.849 \mathrm{t} / \mathrm{m}^{2}$.

$$
\begin{aligned}
& q_{c r m}=\left[\frac{P_{b o l t}}{S_{b o l t}^{2}}-u\right] \times\left[\frac{\left(1+\sin \varphi_{j}\right)}{1-\sin \varphi_{j}}\right] \\
& \tan \varphi_{j}=\frac{J_{r}}{J_{a}}
\end{aligned}
$$




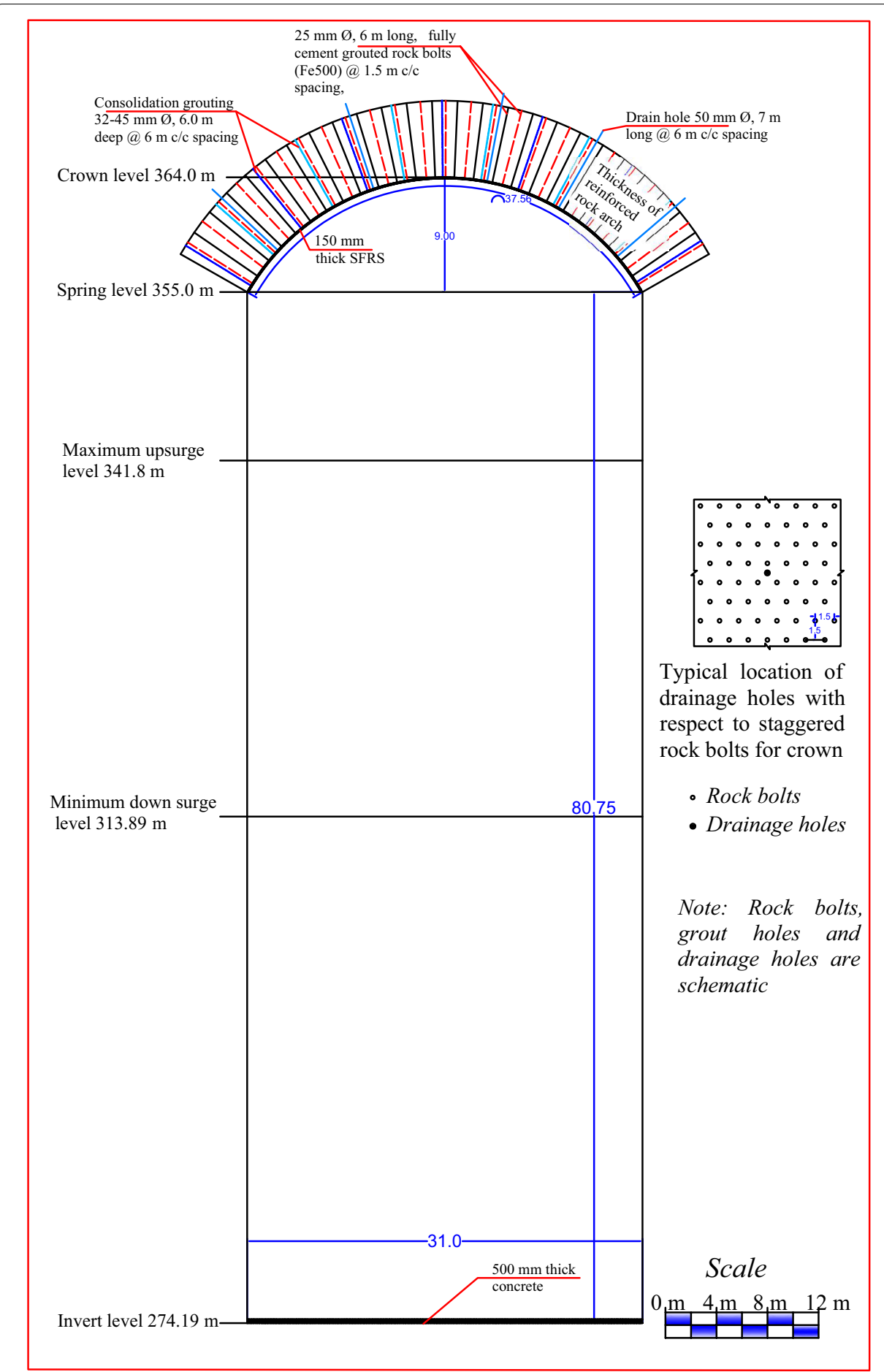

Fig. 2 Support system of surge pool cavern 
where $q_{c r m}=$ minimum uniaxial compressive strength of reinforced rock mass, $P_{b o l t}=$ capacity of bolt or tension in bolt (tones), $S_{\text {bolt }}=$ spacing of bolt ( $1.5 \mathrm{~m}$ for roof), $u=$ seepage pressure in the rock mass $\left(0.00 \mathrm{t} / \mathrm{m}^{2}\right), J_{r}=$ Joint roughness number, $J_{a}=$ Joint alteration number.

Effective thickness of reinforced rock arch is calculated as per Eq. (16) and it is $4.775 \mathrm{~m}$ for surge pool crown:

$$
l_{\text {arch }}^{\prime}=l-\frac{F A L}{2}-\frac{S_{\text {bolt }}}{4}+S_{\text {rock }}
$$

where $l^{\prime}=$ effective thickness of reinforced rock arch, $l=$ length of bolt $(6 \mathrm{~m}), F A L=$ fixed anchor length $(2.5 \mathrm{~m}), S_{\text {bolt }}=$ spacing of bolt $(1.5 \mathrm{~m}), S_{\text {rock }}=$ average spacing of joints $(0.400 \mathrm{~m})$.

Mobilization factor $\left(F_{s}\right)$ for the rock bolt is calculated as per Eq. (17). Singh et al. [20] proposed this equation after back analysis of Barton et al. [2] support systems case studies. For the surge pool roof, $F_{s}$ values are varying from 3.898 to 4.461 :

$$
F_{s}=9.5 \times p_{\text {roof }}^{-0.35}(\text { for rock anchor \& full column grouted rock bolt })
$$

where $F_{s}=$ mobilization factor for rock bolt, $p_{\text {roof }}=$ roof support pressure.

The capacity of grouted rock arch is calculated by the Eq. (18). The minimum and maximum grouted arch capacity for surge pool roof calculated is $4.289 \mathrm{t} / \mathrm{m}^{2}$ and $4.950 \mathrm{t} /$ $\mathrm{m}^{2}$ respectively.

$$
p_{g t}=\frac{2 q_{g t} \times l_{g t}}{B F_{g t}}
$$

where $p_{g t}=$ support capacity of grouted arch $\left(\mathrm{t} / \mathrm{m}^{2}\right), q_{g t}=\mathrm{UCS}$ of grouted rock mass, $l_{g t}=$ thickness of grouted arch, $B=$ size of opening, $F_{g t}=$ mobilization factor for grouted arch.

For grouted arch, mobilization factor $\left(F_{g t}\right)$ is calculated from Eq. (19). For surge pool roof $F_{g t}$ values are varying from 3.898 to 4.499 . Total capacity of support system estimated for the entire portion of the heading portion of surge pool is given in Table 5.

$$
F_{g t}=9.50 \times p_{\text {roof }}^{-0.35}
$$

\section{Conclusions}

Heading portion of the surge pool was excavated using pilot and side slashing because size of the cavern is very large. 3D geological mapping of pilot is very important for predicting geologic conditions up to bottom level and for side slashing. Rock mass characterization was done on the basis of geological logging data and in-situ testing. Support pressure estimation was based on tunnel quality index. 3D geological logging data was also used for recommendations of cavern support system and selecting supplemental rock bolt locations. For support design empirical approach was used which is backed by a systematic approach to rock mass classification. For structural stability the rock support arrangement includes steel fibre reinforced shotcrete, rock bolt, grouting and drainage hole provisions. Efficacy of support system is checked and results showed that 
Table 5 Capacity of support system for roof

\begin{tabular}{|c|c|c|c|c|c|}
\hline Chainage (m) & $\begin{array}{l}\text { Ultimate } \\
\text { support } \\
\text { pressure }\left(t / \mathrm{m}^{2}\right)\end{array}$ & $\begin{array}{l}\text { Capacity of } \\
\text { SFRS }\left(t / \mathrm{m}^{2}\right)\end{array}$ & $\begin{array}{l}\text { Capacity of } \\
\text { rock bolt (t/ } \\
\left.\mathrm{m}^{2}\right)\end{array}$ & $\begin{array}{l}\text { Capacity of } \\
\text { grouting }(\mathrm{t} / \\
\left.\mathrm{m}^{2}\right)\end{array}$ & $\begin{array}{l}\text { Total support capacity of } \\
\text { support system }\left(t / \mathrm{m}^{2}\right)\end{array}$ \\
\hline $0.0-10$ & 12.746 & 8.188 & 3.408 & 4.950 & 16.546 \\
\hline $10-25$ & 8.769 & 8.188 & 2.990 & 4.343 & 15.521 \\
\hline $25-50$ & 9.075 & 8.188 & 3.026 & 4.395 & 15.609 \\
\hline $50-75$ & 8.463 & 8.188 & 2.952 & 4.289 & 15.429 \\
\hline $75-100$ & 8.667 & 8.188 & 2.978 & 4.325 & 15.491 \\
\hline $100-125$ & 8.769 & 8.188 & 2.990 & 4.343 & 15.521 \\
\hline $125-150$ & 9.891 & 8.188 & 3.118 & 4.530 & 15.766 \\
\hline $150-175$ & 8.463 & 8.188 & 2.952 & 4.289 & 15.429 \\
\hline $175-200$ & 9.279 & 8.188 & 3.049 & 4.430 & 15.667 \\
\hline $200-239$ & 8.769 & 8.188 & 2.990 & 4.343 & 15.521 \\
\hline $239-260$ & 9.177 & 8.188 & 3.038 & 4.413 & 15.639 \\
\hline $260-285$ & 9.279 & 8.188 & 3.049 & 4.430 & 15.667 \\
\hline $285-300$ & 8.769 & 8.188 & 2.990 & 4.413 & 15.521 \\
\hline $300-357$ & 8.667 & 8.188 & 2.978 & 4.325 & 15.491 \\
\hline
\end{tabular}

the estimated support system is adequate for crown. Minimum and maximum factor of safety estimated is 1.30 and 1.82 respectively while average factor of safety is 1.70 . It is extrapolated that same rock types will be exposed during the benching of surge pool from El 355.00 to El $274.19 \mathrm{~m}$ and this data will be very helpful for the selection of methodology of benching down and selection of support system. It was recommended that real time engineering geological monitoring should be done during the benching down and accordingly support system should be modified. Real time engineering geological monitoring means as-and-when excavation is done, immediately 3D geological mapping should be done.

Acknowledgements

This paper is a part of sponsored project by M/s MEIL, so we sincerely thank the management of MEIL for the same. Authors are thankful to Dr. H.S. Venkatesh, Director NIRM for the permission to send the manuscript for publication, encouragement and technical guidance.

Authors' contribution

LGS and DSR collected the data from the site, PJ finalize the figures and tables while AKN analize the data and finalize the manuscript. All authors read and approved the final manuscript.

\section{Funding}

This study was funded by Megha Engineering Infrastructure Development, under the Grant Number EG1802 to Ajay Kumar Naithani.

\section{Declarations}

Competing interests

All authors declare that they have no competing interests.

Received: 24 September 2020 Accepted: 21 January 2022

Published online: 02 March 2022

\section{References}

1. Anon (2017) Report on determination of in-situ stress parameters at the proposed underground surge pool of Palamuru Rangareddy lift irrigation scheme lift-Il-pumping station. Unpubl. NIRM Report No. GE1704C

2. Barton N, Lien R, Lunde J (1974) Engineering classification of rock masses for the design of tunnel support. Rock Mech 6:189-236. https://doi.org/10.1007/BF01239496 
3. Barton N, Løset F, Lien R, Lunde J (1981) Application of Q-system in design decisions concerning dimensions and appropriate support for underground installations. Subsurf Sp Environ Prot Low Cost Storage Energy Savings 2:553-561. https://doi.org/10.1016/B978-1-4832-8421-7.50080-6

4. Bieniawski ZT (1989) Engineering rock mass classification. Willey, New York

5. Grimstad E, Barton N (1993) Updating of the Q-system for NMT. In proceedings of the international symposium on sprayed concrete, Fagernes, Oslo, p 46-66

6. Grimstad E, Kankes K, Bhasin R, Magnussen A, Kaynia A (2002) Rock mass quality Q used in designing reinforced ribs of sprayed concrete and energy absorption. In proceedings: international symposium on sprayed concrete, Davos, p 134-142.

7. GSI (1995) Geological quadrangle maps of GSI: No. 57E (2004) and 56L (1995) published by Geological Survey of India.

8. IS 13365-PART 2 (1992) Quantitative classification systems of rock mass—guidelines, part-2, rock mass quality for prediction of support pressure in underground openings. Bureau of Indian Standards, New Delhi

9. IS 15026 (2002) Tunnelling methods in rock masses_-guidelines, Bureau of Indian Standards, New Delhi

10. Naithani AK (2017) Geotechnical investigations and support design of underground pump house cavern-a case study from lift irrigation project. Int J Geotech Geol Eng 35:2445-2453. https://doi.org/10.1007/s10706-017-0227-7

11. Naithani AK, Singh LG, Jain P (2017) Rock mass characterization and support design for underground additional surge pool cavern—a case study, India. Geomaterials 07:64-82. https://doi.org/10.4236/gm.2017.72006

12. Naithani AK, Rawat DS, Jain P, Singh LG, Srisailam M, Venkatramaiah V (2019) Rock mass characterization and support system for underground pump house cavern - a case study, India. In Proceedings 14th International Conference on Underground Construction Prague 2019, paper no. S4-OP7, p 1-9

13. Naithani AK, Jain P, Rawat DS, Singh LG (2020) Rock mass characterization for the underground surge pool caverna case study, India. J Geol Soc India 96:265-271. https://doi.org/10.1007/s12594-020-1546-5

14. NGI (2013) Using the Q-system—rock mass classification and support design. NGI Publication, Norway

15. Prakash D, Sharma IN (2011) Metamorphic evolution of Karimnagar granulite terrane, Eastern Dharwar Craton, South India. Geol Mag 48:112-132. https://doi.org/10.1017/s0016756810000488

16. Ramam PK, Murty VN (2012) Geology of Andhra Pradesh. Geological Society of India

17. Reddy GT, Rao VN (1991) Study of granitic rocks in Gadwal Makhtal area, Mahbubnagar District, Andhra Pradesh. Rec Geol Surv India 124:256-258

18. Sharma R, Murthy CVVS, Mishra VP, Nagaraju GHC, Singh RK (2008) Study of structural pattern through aeromagnetic data for mineral prospecting and Kimberlite clan rocks in an area around Mahbubnagar, A.P. J Geol Soc India 72:175-189

19. Singh B, Jethwa JL, Dube AK, Singh B (1992) Correlation between observed support pressure and rock mass quality. Tunn Undergr Space Technol 7:59-74

20. Singh B, Viladkar MN, Samadhiya NK (1995) A semi-empirical method of the design of support systems in underground openings. Tunn Undergr Space Technol 3:375-383

21. Singh B, Goel RK (2011) Engineering rock mass classification. Elsevier Inc. Publication, Amsterdam

22. Stillborg B (1994) Professional users handbook for rock bolting. Trans Tech Publication, Clausthal-Zellerfeld

\section{Publisher's Note}

Springer Nature remains neutral with regard to jurisdictional claims in published maps and institutional affiliations.

\section{Submit your manuscript to a SpringerOpen ${ }^{\circ}$ journal and benefit from:}

- Convenient online submission

- Rigorous peer review

- Open access: articles freely available online

- High visibility within the field

- Retaining the copyright to your article

Submit your next manuscript at $\boldsymbol{\nabla}$ springeropen.com 